High-Resolution Marine Seismic

Reflection Data Acquisition

Using an Engineering Seismograph

\title{
DEP
}

DEP

TN

269.84

.635

1904 


\section{HIGH-RESOLUTION MARINE SEISMIC REFLECTION DATA ACQUISITION USING AN ENGINEERING SEISMOGRAPH}

\author{
MINERALS MANAGEMENT SERVICE YEAR 9 \\ FINAL TECHNICAL REPORT, 1994 \\ AGREEMENT NUMBER 14-12-0001-30666
}

by

WALDNER, Jeffrey S., NJ Geological Survey, CN427, Trenton, NJ 08625 (609) 984-6587 - Drexel University, Dept. Civil and Architectural Engineering, Philadelphia PA; SHERIDAN, Robert E., Rutgers University, Dept. of Geological Sciences, New Brunswick,New Jersey, 08903 (908) 932-2044; HALL, David W., NJ Geological Survey; ASHLEY, Gail M., Rutgers University, Department of Geological Sciences.

In addition to this Technical report, the research program has resulted in the following presentations (included following this report) before professional societies:

Waldner, J. S., Sheridan, R. E., Hall, D. W., and Ashley, G. M., 1994, Highresolution marine seismic reflection data acquisition using an engineering seismograph: Symposium on the Application of Geophysics to Engineering and Environmntal Problems, Environmental and Engineering Geophysical Society, March 27-31, Boston, Massachusetts.

Waldner, J. S. Sheridan, R. E., Carey, J. S., Ashley, G. M. and Henne, R. G. Jr., 1993, Digital continuous seismic reflection profiles of New Jersey inner shelf sand ridges: The Geological Society of America 28th Annual Northeast Section Annual Meeting March 22-24, Burlington, Vermont. 


\section{HIGH-RESOLUTION MARINE SEISMIC REFLECTION DATA ACQUISITION USING AN ENGINEERING SEISMOGRAPH}

WALDNER, Jeffrey S., NJ Geological Survey, CN427, Trenton, NJ 08625 (609) 984-6587 Drexel University, Dept. Civil and Architectural Engineering, Philadelphia PA; SHERIDAN, Robert E., Rutgers University, Dept. of Geological Sciences, New Brunswick,New Jersey, 08903 (908) 932-2044; HALL, David W., NJ Geological Survey; ASHLEY, Gail M., Rutgers University, Department of Geological Sciences.

\section{ABSTRACT}

A digital single-channel seismic reflection system was developed to acquire continuous profiling data by interfacing a conventional analog system with a land-based digital signalenhancement engineering seismograph. Digital profiles are enhanced by trace static correction, deconvolution, automatic gain scaling, weighted horizontal stacking and digital filtering. Problems common to analog data, such as wave-motion effects of surface sources, waterbottom reverberation, multiple reflections, and bubble-pulse width can be addressed by the processing. The fast firing rate for analog records is maintained while a trigger-divider sends a slower trigger rate to the digital seismograph. An auto-save feature with an automatic rollalong switch groups adjacent traces to files, eliminating system limitations of the mass-storage device.

The digital data were collected to map sand ridges of the inner continental shelf off New Jersey for beach sand replenishment surveys. The seismic tracklines are correlated to vibracores and known geologic stratigraphy. The digital data exhibit reflections from layers less than 1 meter thick. Synthetic seismograms constructed from the vibracore information show these internal reflectors are caused by shelly gravel/medium sand interfaces. Global Positioning System (GPS) was used to plot real-time position as well as obtain a navigational accuracy within 10 meters. The combination of the analog system with the land-based seismograph offers a less expensive technique for digital acquisition and processing. This provides improved results over older analog data.

\section{ACKNOWLEDGMENT}

This research was supported by the Minerals Management Service, U. S. Department of the Interior, under MMS Agreement Numbers 14-12-0001-30666 and 14-35-0001-30643. The authors gratefully acknowledge the assistance of the members of the New Jersey Geological Survey; Rutgers University, Department of Geological Sciences; and the Bureau of Marine Water Classification, Department of Environmental Protection and Energy, who assisted in the marine surveys.

\section{INTRODUCTION}

For the past two years the New Jersey Geological Survey and Rutgers University, Department of Geological Sciences, have conducted digital high-resolution single-channel 
marine seismic surveys using a conventional analog equipment paired with a land-based engineering seismograph. This purpose is part of an ongoing project to map marine sediments for sand deposits that are suitable for beach replenishment. The system is to capitalize on the processing and archival capabilities of digital data.

Although analog seismic equipment may be adequate for many objectives, including surveys for beach sand resources, for detailed or large surveys, analog paper records and tapes quickly become a data-management nightmare. Post-acquisition processing is commonly limited to tape playback through the analog unit. Previous investigators have sought to minimize data-quality degradation experienced with analog recording by utilizing digital analog tape (DAT) for subsequent analog playback or digital conversion. Although DAT greatly improves data-record quality, the authors feel that current digital engineering seismographs have analog-to-digital conversion, dynamic-range, and signal sampling advantages, compatible with seismic sources in the less-than-1.2-kilohertz range.

The enhanced digital system had to meet certain minimal criteria to prove its superiority to an analog survey program. These are:

a) low incremental cost compared to a stand-alone analog unit

b) ease of implementation using off-the-shelf components

c) maintenance of a high-resolution capability with the seismic source

d) conventional data-storage formats (SEG1, SEG2 or SEGY)

e) suitability to available digital processing software

f) data transfer and storage on a microcomputer

g) a suitable method for correlating data to geographic position

\section{DATA ACQUISITION SYSTEM}

The analog system is an ORE Geopulse ${ }^{\mathrm{TM}}$ system in which a towed catamaran with a magnetorestrictive diaphragm having a peak frequency of about 1.0 kilohertz is the seismic source. The power supply (Model 5420A) provides several energy levels of 105, 175, 280, 350 and 455 joules. A Geopulse ${ }^{\mathrm{TM}}$ receiver (Model 5210A) and EPC graphic recorder, control the firing rate, frequency filtering, gain scaling, before plotting on electrosensitive paper. A digitizing dual trace oscilloscope (Hewlett Packard Model 54200A/D) is used to monitor the incoming raw and filtered signal.

The digital system receiver is a Bison Instruments $9024^{\mathrm{TM}}$ 24-channel engineering seismograph. Analog-to-digital conversion is 16-bit with digital instantaneous floating point. Wave noise (a low-frequency high-energy signal) requires the conditioning of the raw signal by the analog-receiver low-cut frequency filters before entering the first channel of the digital seismograph. Digital filters on the digital seismograph are, therefore, selected with due regard to the analog filters to minimize signal aliasing. The Bison is equipped with an auto-save feature where data are routed to internal storage after a pre-set number of enhancements. For the marine survey each shotpoint is saved without signal enhancement. Internal data storage is an 80-megabyte hard disk. 
A trigger-divider and automatic roll-along switch are used to overcome digital recording and storage problems. A trigger-divider sends a slower trigger rate to the digital seismograph, while maintaining the fast firing-rate for analog records. The slower digital trigger-rate serves three purposes. First, it adapts the firing rate normally used by analog units which is too fast (often 2-5 triggers per second) for the cycle time of the engineering seismograph; second, it maintains output of an analog paper copy for cursory interpretation and overall quality control; and third, it reduces the amount of digital data collected to a manageable but representative size. An automatic roll-along switch (developed by Bison Instruments) by grouping adjacent traces to files, overcomes limitations of the seismograph's mass-storage device and the microcomputer. The 12-channel roll-along switches the single channel input to the next trace after each trace-sampling cycle. With the auto-save feature set to 12 enhancements before saving, the roll-along groups 12 sequential traces to a single file. The system is limited to 12 instead of 24 channel files so that the auto-save cycle time is shorter than the digital firing-rate.

The digital operating system limits downloading to 999 files or fewer, even though, a larger number can be saved by the seismograph. In addition, download time for hundreds of small files to a microcomputer increases geometrically to unfeasible limits. For most survey situations, at 12 traces per file, the 80-megabyte hard disk can accommodate nearly 12,000 recorded traces. This is enough for a single day of data collection, permitting downloading overnight. For example, with an analog firing rate of 3 shots-per-second, and a trigger-divider ratio of 10:1, approximately 11 hours of continuous digital recording is possible.

Survey positioning via the Global Positioning System (GPS) enables one to plot real-time position and to obtain navigational accuracy within 10 meters following processing. The seismic data is correlated to the GPS data by synchronization of the seismograph clock to the GPS; thereby, matching seismic data file-header time-tags to geodetic coordinates.

\section{FIELD EXAMPLE - Beach-Sand-Replenishment Sand Ridges}

The purpose of the initial year's survey was to examine the operational effectiveness of the digital seismic system in previously studied areas. The surveys focused on sand ridge deposits, which are linear features of shallow topographic relief 3-10 meters trending southwest-northeast along the inner continental shelf off New Jersey. These concentrated sand deposits are commonly the most suitable economical sources of sand for beach replenishment.

A digital survey trackline traversed a shore detached ridge off Long Beach Island, (figures 1a and 1b) in an area previously studied by Ashley and others, 1991 and Wellner and others, 1993. Synthetic seismograms constructed from Vibracores of 1-6 meters depth (Esker, 1992) were correlated to the seismic stratigraphic data.

The digital seismic data were processed using the Eavesdropper ${ }^{\mathrm{TM}}$ software (Kansas Geological Survey, 1993). Processing of the section shown in figure 2 followed routines using trace static correction, deconvolution, trace normalization, weighted horizontal stacking and digital filtering. Unfortunately, processing failed to minimize the effects of water bottom reverberation, caused primarily by the use of the intermediate energy output of 280 joules for the Geopulse ${ }^{\mathrm{TM}}$ in shallow waters. This problem was corrected in subsequent surveys by reducing the Geopulse ${ }^{\mathrm{TM}}$ output to 105 joules. 
Figure 1. A. Study area location map within mid Atlantic bight, from Ashley, 1991. B. Bathymetric map of the study area showing important geomorphic features and location of digital seismic section shown in figure 2. Modified from Ashley, 1991. Contour interval $=2$ meters. Depth is in meters from sea level NGVD of 1929.

B.

A.

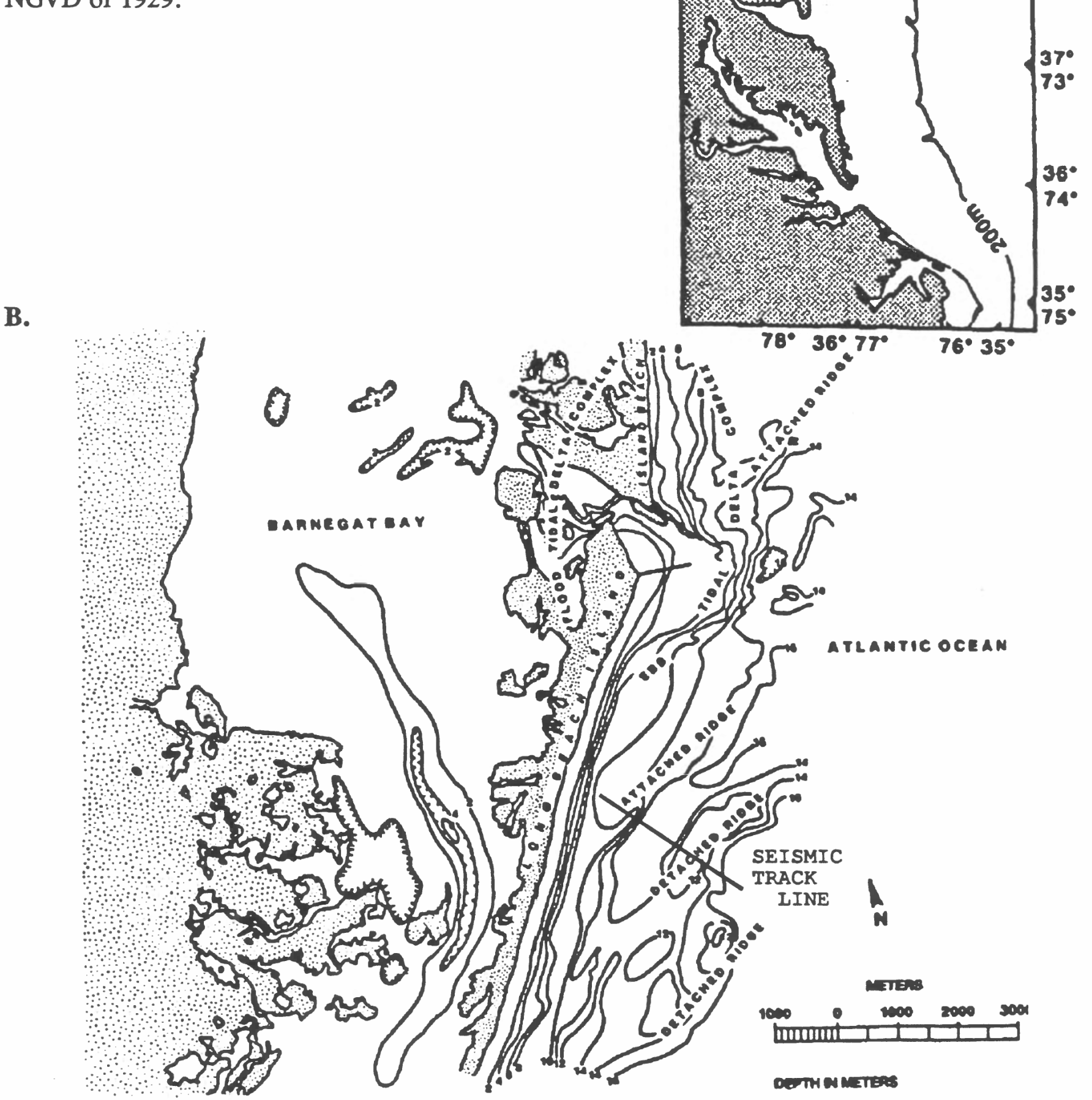


Three major traceable unconformities (R1, R2 and R3) in the shallow subsurface are shown in the seismic section (figure 2). The digital data also exhibit reflections from layers less than 1 meter thick. Synthetic seismograms constructed from the vibracore information show that these internal reflectors are caused by shelly gravel/medium sand interfaces. Internal reflections of the detached sand ridge downlap onto the erosional surface, R3. This indicates that the shore ridge is a depositional feature. At the landward (northwest) edge of the section, steeply dipping internal reflectors between $\mathrm{R} 1$ and $\mathrm{R} 2$ are interpreted as mid-Wisconsin (approximately 55,000 years ago) barrier-island shoreface deposits.

\section{RESULTS AND CONCLUSIONS}

The New Jersey Geological Survey and Rutgers University, Department of Geological Sciences have collected more than 250 line-kilometers of digital seismic data utilizing the digital system. Analog and digital records were used for processing and for interpretation. These surveys, combined with pre-existing data, have enabled us to identify nearly 23 million cubic meters of sand for possible use in restructuring damaged shoreline and beaches along the New Jersey coast. The digital data have proven to be advantageous in both operational cost, data management, geographic accuracy, and enhanced data quality.

\section{DISCLAIMER}

The views and conclusions contained in this document are those of the authors and should not be interpreted as necessarily representing the official policies, either express or implied, of the U. S. Government.

The use of trade, brand, or commercial names is for identification purposes only and does not indicate endorsement by the authors or their affiliated agencies.

\section{CITED REFERENCES}

Ashley, G. M., Wellner, R. W., Esker, D., and Sheridan, R. E., 1991, Clastic sequences developed during late quaternary glacio-eustatic sea level fluctuations on a passive margin: Example from the inner continental shelf near Barnegat Inlet, New Jersey: Geological Society of America Bulletin v. 103, p. 1607-1621, 13 figs., 1 table.

Esker, Dominic, 1992, Synthetic seismograms from vibracores: a tool for correlating the seismic record to the sediment record of Barnegat Inlet, New Jersey: unpublished M.S. thesis Rutgers University, New Brunswick, NJ 198 p.

Kansas Geological Survey, University of Kansas, 1993, Eavesdropper seismic reflection processing software for the microcomputer: Kansas Geological Survey, University of Kansas, Lawrence KS.

Wellner, R. W, Ashley, G. M., and Sheridan, R. E., 1993, Seismic stratigraphic evidence for a submerged middle Wisconsin barrier: Implications for sea-level history: Geology, v. 21 , p. $109-112$, p. $109-112,4$ figs. 


\section{A.}

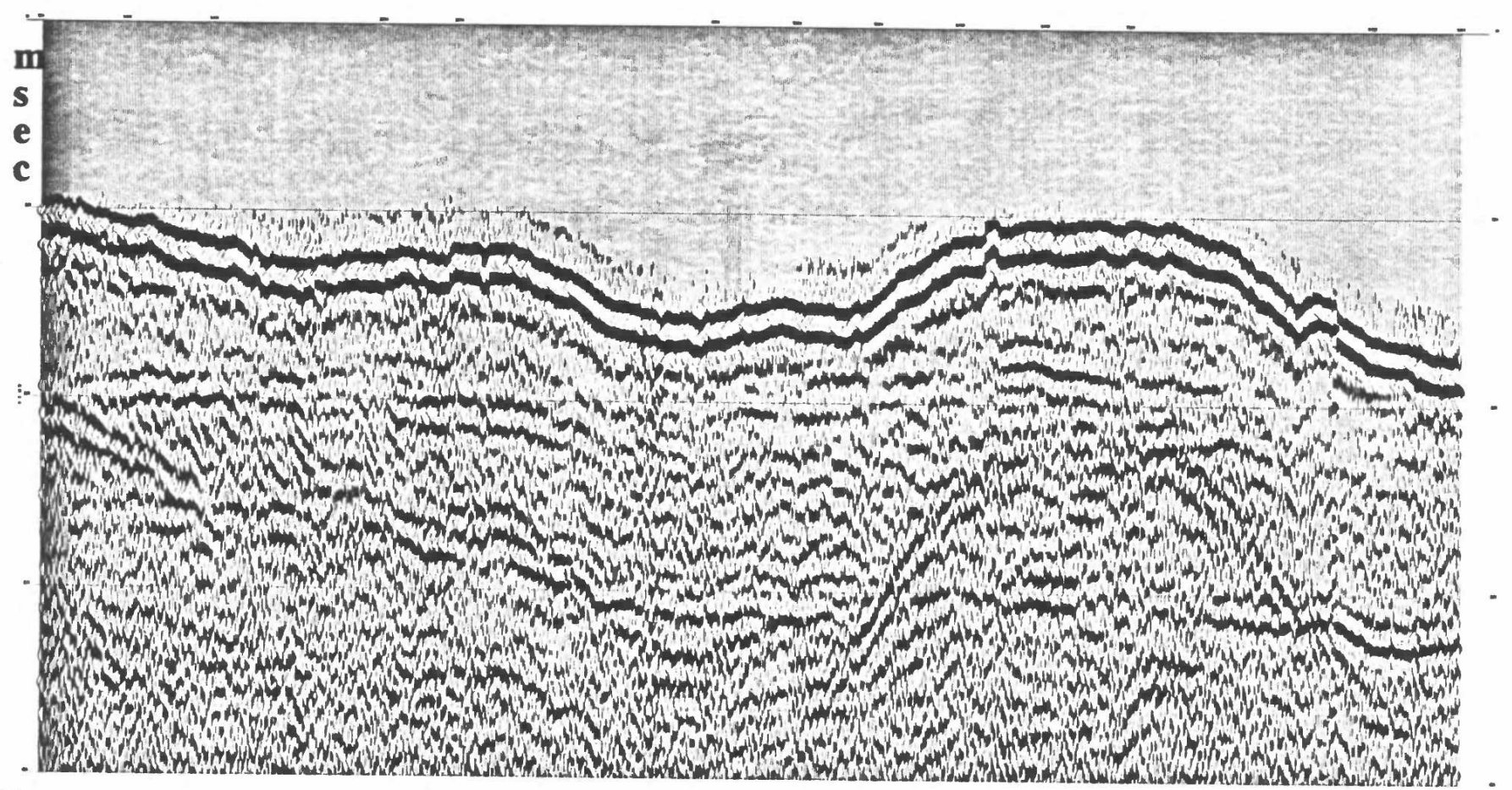

B.

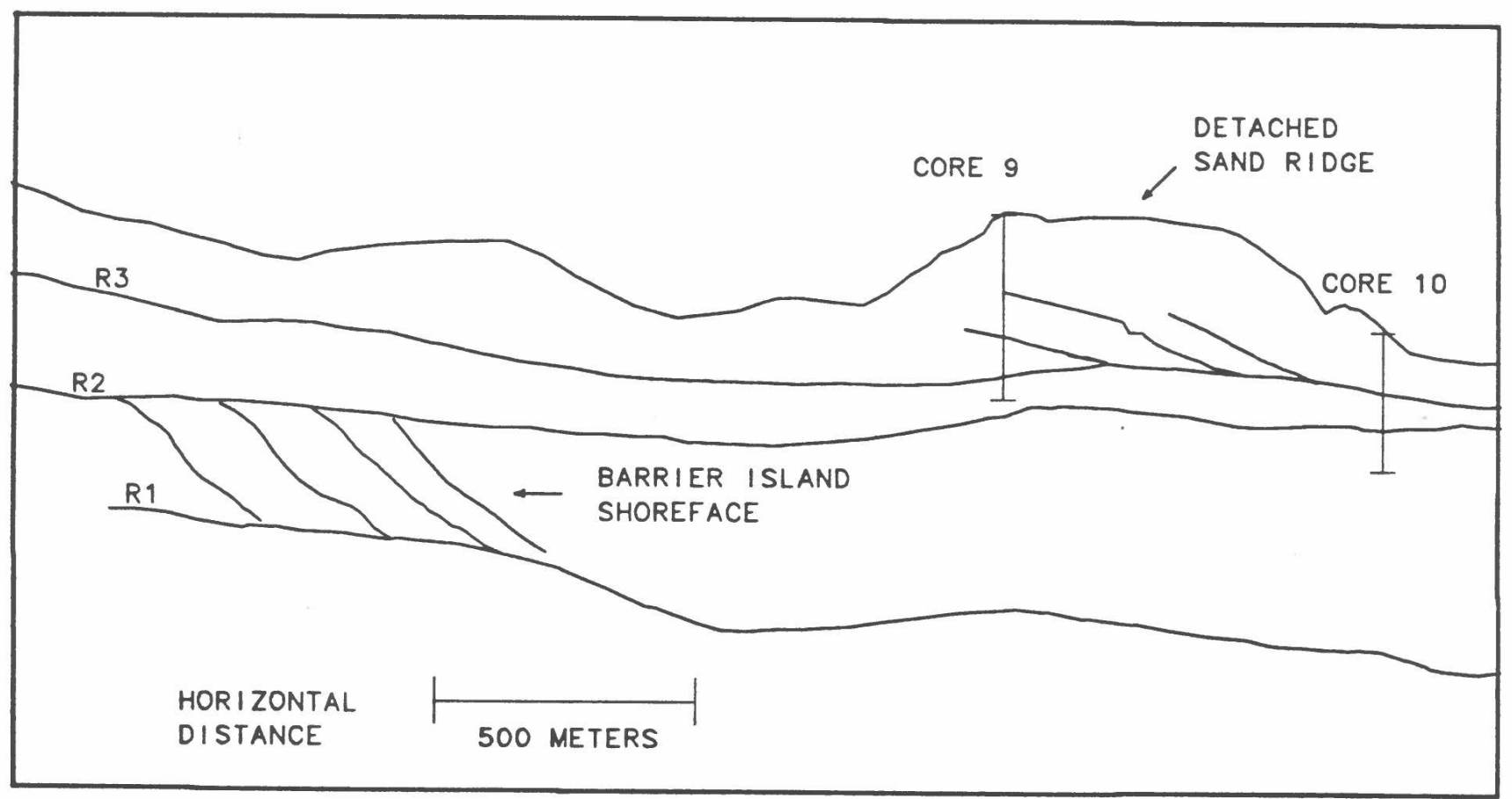

Figure 2. Digital marine seismic section, land to left ocean to right A. Processed section across detached sand ridge. Horizontal divisions are every 10 milliseconds. B. Interpreted section (from cores 9 and 10) showing southeast dipping shallow reflections. Internal reflectors of the sand ridge and steeply dipping barrier island shoreface deposits also shown. 


\section{8th Annual \\ Northeastern Section}

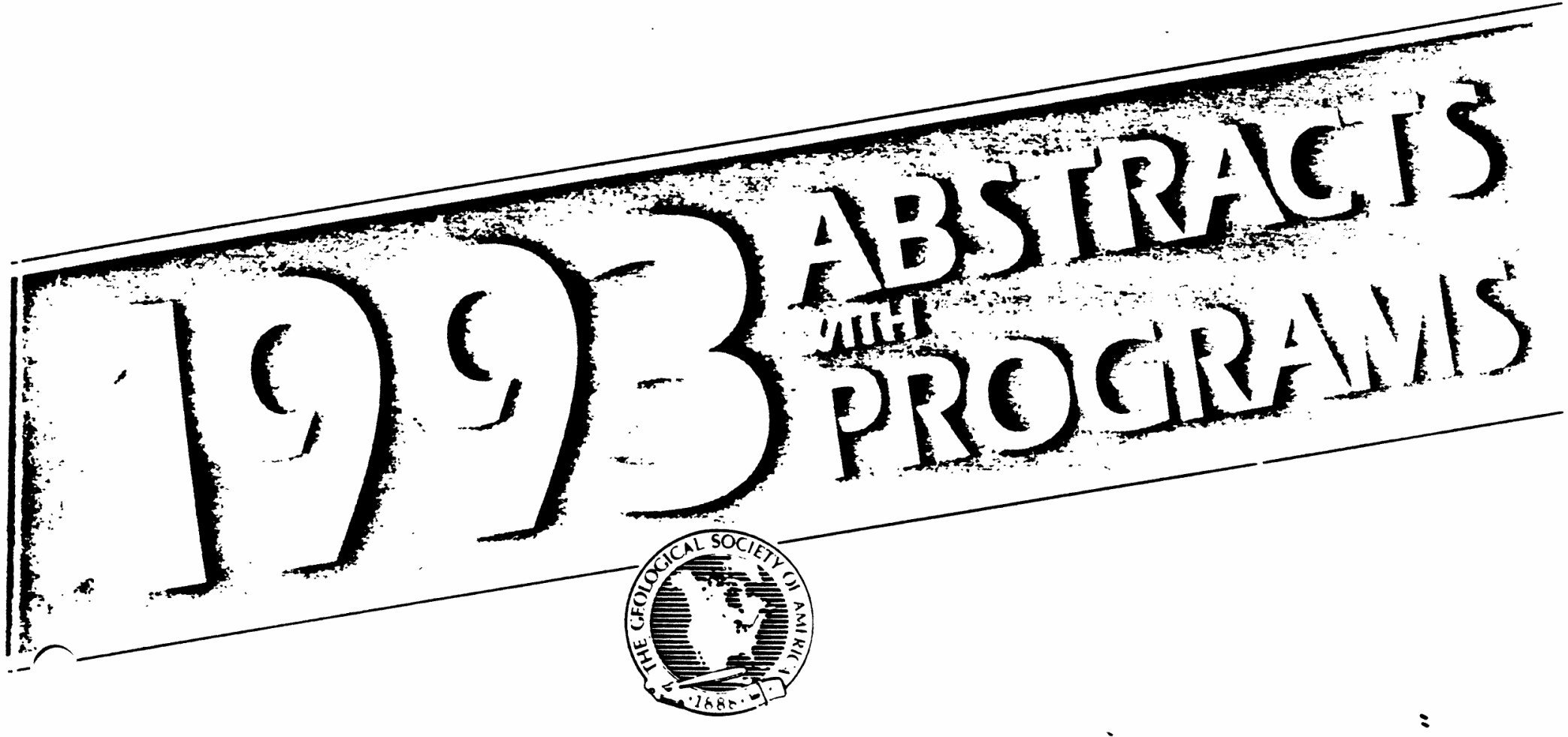

The Geological Society of America with

Eastern Section of the SEPM Northeastern Section of the Paleontological Society

Eastern and New England Sections of the National Association of Geology Teachers and

Association of Women Geoscientists

March 22-24, 1993

Sheraton Hotel and Conference Center Burlington, Vermont

A-1 
5 remäth Iuak12s*: LARGE-SCALE, WIND-DRIVEN

- MOTION IN LAKE CHAMPLAIN 1006022\} .......... 9:40 A

20:00 A

6 J. Saylor", I. O. Masloy, P. I. Masley,

J. Miller: PHYSICAL PROCESSES DRIVING

HIGH-SPEED CURRENTS IN LAKE CHAMPIAIN

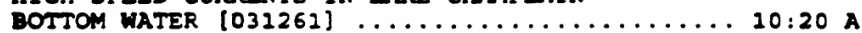

7 P. 2. Marloy*, T. O. Manloy:

GEDIMENT-CURRENT INTERACTIONS AT VALCOUR

ISLAND, ILAKE CHAMPIAIN--A CASE OF KELICAL

FLOW IN THE BOTTOM BOUNDARY LAYER (002979) ... 10:40 A

- zllen 2. Mecray*, Jobr W. IIzg: an

HISTORICAL ASSESSMENT OF TRACE METAL

ACCUMULATION IN LAKE CHAMPILAIN, VERMONT

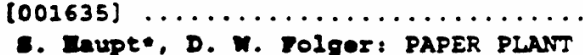

2 2. B. TaUPt: D. W. TOlger: PAPER PLANT

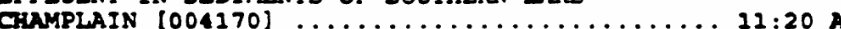

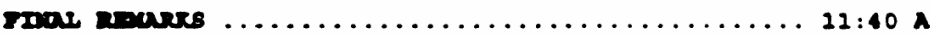

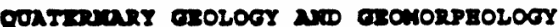

Gheraton Conference Center. Emerald Grand Ballroom, Salon 2 , B:00 A.M.

Largy Ward and Thomas Lowell, Presiding

1 Rabert 8. Moreacy": A BURIED MARINE DEPOSITIONAI SEQUENCE (PRESUMPSCOT FM.) N OF THE MARINE LIMIT, WATERBORO, MAINE [028708] .......................... 8:00 A

2 Chrletopher C. DOrIOD:' A CHRONOLOGY OF DEGLACIATION AND ACCOMPANYING MARINE TRANSGRESSION IN MAINE 1004177$) \ldots \ldots \ldots \ldots \ldots$ 8:20 A

3 LATrY 0 . Mard*: QUATERNARY SEDIMENTATION IN A TIDE-DOMINATED ESTUARY, NORTHERN NEW

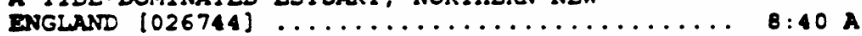

4 J. Kucouricz, Jx.*, J. Bbort, C. Raequid.

R. Shorran, R. Hothaway, J. Cardaez,

R. Mlunich, J. Waber, I. Woblford, J. Jranz.

- Ex11lon: unUSUal configuration OF THE DEVONIAN-PIEISTOCENE UNCONFORMITY IN THE SUSOUEHAANNA VALLEY, ONEONTA, NEW YORK EVIDENCE FOR A SUBGLACIAI MELTWATER INLET TO GLACIAI LAKE OTEGO (029669) ...........

9:00 A

5 Irle tanl1", Davld Deeimone: ASYNCHRONOUS ICE LOBE RETREAT AND GLACIAI LAKE BASCOM: DEGLACIATION OF THE HOOSIC AND VERMONT VALLEYS, SOUTHWESTERN VERMONT $1028 B 99$ )

6 Theane $\nabla$. Lowe11": THE LATE WISCONSIN BOUNDARY OF THE SCIOTO SUBLOBE NEAR CHILIICOTHE, OHIO (003407) .............. 9:40 A

10:00 A

7 w. Rol and Cehrela", Daniel P. Bolkan, Joseph T.

Zolley, Din Cong, Bryen R. Poarce:

RELAIIVE SEA-LEVEL TRENDS ALONG THE COAST OF MAINE DURING THE PAST $500014 C$ YEARS

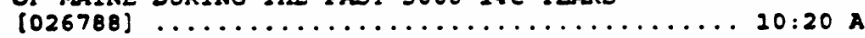

D. M. Cove110\%, X. A. Inotta, P. R. Pizet,

C. I. MeClengen: EROSIONAL DYNAMICS AND MORPHOLOGICAL ANALYSIS ALONG THE SOUTHEASTERN LAKE ONTARIO SHORELINE, NEW YORK STATE 1029412 ] .................. 10:40 A

- Matthow Cohn*, R. Cralo Rochol: THE RELATIVE ROLE OF GEOMORPHIC PROCESSES IN STORM RECOVERY OF WASHOVER SITES ON THE VIRGINIA BARRIER

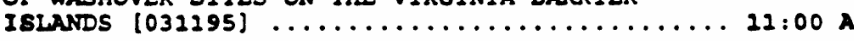

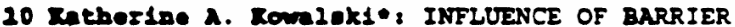
ISLAND STRATIGRAPHY AND BATHMNETRY ON SHORELINE CHANGE (031076) $\ldots \ldots \ldots \ldots \ldots \ldots \ldots$ 21:20 A

12 LaWrence $M$. QAtEo", BANK EROSION IN COLD REGIONS 1025908$] \ldots \ldots \ldots \ldots \ldots \ldots \ldots \ldots \ldots$ 21:40 A

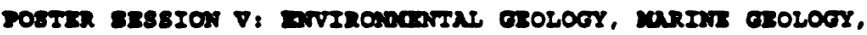

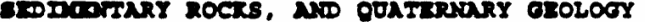

Sheraton Convention Center, Lake Champlain Exhibition Hall, 0:00 A.M. - 22:00 Noon

Authore will be prewent from 9:00 to 11:00

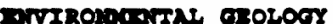

Potor Fadtb*, W1111an coodhas, Ronald cole,

IaUsa Mbbott: USE OF PENETRATIVE INVESTIGATIONS AND PUMPING TEST DATA TO REVISE LARGE SCALE MAPS OF SUFICIAL AOUIFERS IN NORTHERN

CATTARAUGUS COUNTY, NEW YORK [020188]. stevan J. stokowekd, Jr.•: GEOLOGY OF CONCRETE AGGREGATE QUALITY IN NEW ENGLAND (022700)

Josbua B. Molden*, Anse I. Vecger: THE EFFECT OF HUMAN ACIIVITIES ON THE QUALITY OF GROUND WATER IN THE CHIPUXET AQUIFER, RHODE ISLAND

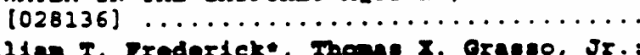

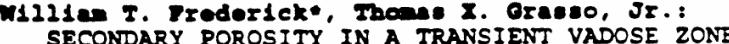

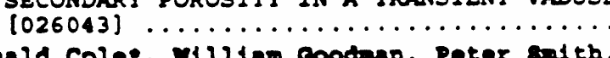

Doma la coln il. SEDIMENTOIOGICAL ANALYSIS OF PIEISTOCENE VALLEY-FILI: USE OF PENETRATIVE INVESIIGAIIONS TO REVISE REGIONAI MAPS OF SURFICIAI GEOLOGY IN NORTHERN CATTARAUGUS,

NEW YORK $(020189] \ldots \ldots \ldots \ldots \ldots \ldots \ldots \ldots \ldots \ldots$
Dav1d $D$. Ca $\ldots$. $\ldots \ldots$ SPONTANEOUS POTENTIAL (SP) GEOPHYSICAL METHOD--APPLICATION TO GROUNDWATER MOVEMIENT IN A GLACIAT SEDIMENT - - PENIKESE ISLAND, MASSACHUSETTS 1024579$\} \ldots \ldots \ldots \ldots \ldots$

rel1y C. Cloyd*, Patr1ek $n$. Coscannon: IANDFII SITING IN NEW YORK: CASE STUDIES CONFIRMING
THE IMPORTANCE OF SITE-SPECIFIC HOROGEOLOGIC INVESTIGATIONS [019675]

moth O Johngom*, APPROPRIATE, AFFORDABLE ASSESSMENT OF GEOENVIRONMENTAL FACTORS CONSTRAINING SUBURBAN EXPANSION AT THE NORTHEASTERN MARGIN OF THE CAPITAL DISTRICT, NEW YORK STATE (031587)

\section{maser arolocy}

Walter A. Darmbardt*, Dandel F. Belknap, Joseph T.

rolloy, etoven $\boldsymbol{u}$. DIekeod: SURFICIAL GEOLOGY OF THE KENNEBEC RIVER PALEODELTA: A PRODUC: OF PLEISTOCENE DEPOSITION, MODIFICATION BY HOLOCENE TRANSGRESSION, NND MODERN SEDIMENT RTWORKING $[027508\}$

Booth 9

D. C. Darber*, D. F. Belkeap, J. T. Rolley: BARRIER BEACH EVOLUTION IN SOUTHWESIERN MAINE: CONSTRAINING A SEDIMENT BUDGET BY ANALYZING DEPOSITIONAL PRODUCTS IN SACO BAY

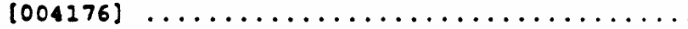

Jeffroy 8 . Weldner*, robert $\mathbf{z}$. Iberidan. Jobn 5 .

Carey, Call $\mathrm{K}$. Abbley, Ilchard G. Eanoe, Jr. DIGITAL CONTINUOUS SEISMIC REFIECTION PROFILES OF NEW JERSEY INNER SHELF SAND

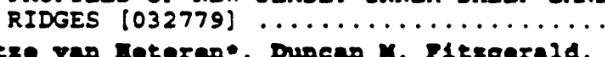

Brtzo van Dotorano, Duncas $K$. Fitsgorald

2. Ienneth Flak, Jr.\& DEVELOPMENT OF THE BARRIER SYSTEM AT FERRY BEACH, MAINE--EVIDENCE OF TRANSGRESSIVE AND REGRESSIVE PHASES [029293]

stopben K. Dlckeor*, Josepb T. Relloy, Dariel F.

Bellemap: STORM-INDUCED SAND TRANSPORT AND BEDFORM GENESIS AT BEACH AND SHOREFACE ENVIRONMENTS OF THE MAINE COAST [004012]

\section{OPDOTRNY ROCKs}

moran A. O1llaeleter", Dele A. Bpriager: "THE HAYSTACKS" : AN UNUSUAL SOFT-SEDIMENT DEFORMATION FEATURE IN THE UPPER DEVONIAN OF NORTHEASTERN PENNSYLVANIA [024706]

I. J. POPP०*, C. U. POAg: MESOZOIC STRATIGRAPHY AND PALEOENVIRONMENTS OF THE EXXON 975-1 WEIL GEORGES BANK BASIN, U.S. NORTH ATLANTIC OUTER CONTINENTAL SHELF 1001639$\} \ldots \ldots \ldots \ldots \ldots \ldots \ldots$ of hIERARchal UPPER SILURIAN STACKING PATTERNS GENERATED BY MILANKOVITCH ORBIIAL

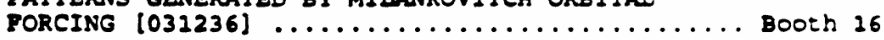

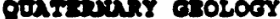

P. u. M121ette" PLANT COManonitiEs AS INDICATORS OF SALT MARSH HYDROLOGY? A STUDY AT COOSE FARE BROOK, SACO, MAINE (027510)

Denlee 2. MUTleeak": PALEOHYDRAUIIC INTERPRETATION AND MORPHOLOGIC RECONSTRUCTION OF THE NORTHERN RIO GRANDE RIVER, COLORADO $[002799\} \ldots \ldots \ldots \ldots$ BOOth 18

Drmeen $X$. Fltsegrald*, Panela A. Mathorp.

Chlog-zued kuo, Gytse Ven Eoteren, l. Renneth

IInk, Jr.. Josoph T. IEJ10Y: ESTUARINE CIRCULATION AND SEDIMENT TRANSPORT TRENDS IN

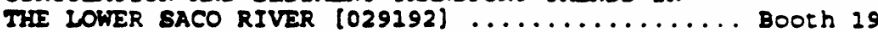

\section{$=$}

E0:5?. 13 


\section{ABSTRACT FORM FOR ALL GSA MEETINGS IN 1993}

Complete all sections (1) through (9) below.

(1) TYPE ABSTRACT COMPLETELY WITHIN THE BLUE LINES BELOW. (10 point type minimum)

\section{No $\quad 32779$}

DIGITAL CONTINUOUS SEISMIC REFLECTION PROFILES OF NEW JERSEY INNER SHELF SAND RIDGES

WALDNER, Jeffrey S., N.J. Geological Suney, CN427, Trenton, NJ 08625; SHERIDAN,

Robert E., CAREY, John S., ASHLEY, Gail M., Dept. of Geological Sciences,

Rutgers University, New Brunswick, New Jersey, 08903; HENNE, Richard, G. Jr., N.J. Geological Survey.

Digital continuous profiling seismic reflection data were collected along three sand ridges of the inner continental shelf off New Jersey in August 1992. The acquisition system consisted of a conventional analog Geopulse ${ }^{T M}$ system interfaced with a land based digital signalenhancement engineering seismograph. The Global Positioning System (GPS) was used to obtain a navigational accuracy within 5 meters after processing. The raw data exhibit seismic reflections from layers less than 1 meter thick. The seismic tracklines were correlated to Vibracores ${ }^{\mathrm{TM}}$ and known geologic stratigraphy. The data show early to late Holocene depositional sequences overtying a mid-Wisconsinan barrier system located at depths of 20 meters. The sand ridges occur as constructive features above an unconformity in an asymmetrical pro. file where cross bedding reflections downlap on the unconformity and dip gently seaward. Synthetic seismograms constructed from Vibracores ${ }^{T M}$ show that these intermal reflections are caused by interfaces between shelly gravel and medium sand. Digital profiles show processing enhancements including trace static correction, deconvolution, automatic gain scaling, weighted horizontal stacking and digital filtering in addition to color panels. Problems common to analog data, such as wave motion effects of surface sources, water bottom reverberation, multiple reflections, and bubble pulse width, are addressed by digital processing. The combination of the analog system with the land-based seismograph offers a less expensive technique for digital acquisition and processing, thus providing improved results over older analog data.

(3) SELECT ONE FORMAT

— WVITED FOR SYMPOSIUM NUMBER: (hirst five words of tith of symposlum)

$\checkmark$ volunteERED FOR DISCIPLINE SESSION

- VOLUNTEERED FOR THEME SESSION NUMBER:

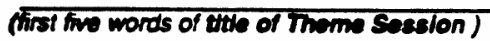

\section{(4) SELECT ONE MODE}

(Be aware that some sessions may have been designated specifically as either "poster" or "oral.")

ORAL-Vorbal presentation betore a seated audience.

I POSTER-Graphic display on poster boards supplemented by speaker comments.

_ EmiEn-Either mode is accoptable.

(5) CHECK IF THIS APPLIES

- WTHORAW-lf the abstract cannot be accepted in the mode I have indicated, please withdraw in.

STUDENT AUTHOR-Please chock here if the presenter is a student author. (information needed for student paper awards.)

(6) INDICATE \% OF THIS PAPER PREVIOUSLY PRESENTED WHERE? WHEN?
(2) CHECK ONE DISCIPLINE (category) below in which reviewers will be best qualified to evaluate your abstract.

\begin{tabular}{|c|c|}
\hline & $\begin{array}{l}\text { I archaeological geology } \\
\text { coal geology } \\
\text { computers } \\
\text { economic geology } \\
\text { engineering geology } \\
\text { environmental geology } \\
\text { geochemistry. } \\
\text { aqueous/organic } \\
\text { geochemistry, other } \\
\text { geology education } \\
\text { geophysics/ } \\
\text { teclonophysics } \\
\text { geoscience information } \\
\text { history of geology } \\
\text { hydrogeology } \\
\text { marine geology } \\
\text { micropaleontology } \\
\text { mineralogy' } \\
\text { crystallography } \\
\text { paleoceanography' } \\
\text { paleoclimatology } \\
\text { paleontology' } \\
\text { paleobotany } \\
\text { petroleum geology } \\
\text { petrology, experimental } \\
\text { petrology, igneous } \\
\text { petrology, metamorphic } \\
\text { planetary geology } \\
\text { Precambrian geology } \\
\text { Ouatemary geology/ } \\
\text { geomorphology } \\
\text { remote sensing } \\
\text { sediments, rarbonates } \\
\text { sediments, clastic } \\
\text { stratigraphy } \\
\text { structural geology } \\
\text { tectonics } \\
\text { o volcanology }\end{array}$ \\
\hline
\end{tabular}

(7) CHECK IF YOU ARE WILLING TO BE A SESSION CHAIR Your Name Ortice Phone Heme Phone

(8) SPEAKER'S IDENTITY AND MAILING ADDRESS Mamo Jeffrey S. Wualdner addrese Nes Jerse, Geologecel Survey addroes CN427 cityrsulp Tranton NS 08625 country USA

Ortice Phone $609-984-6587$

Home Phone $215-579-0115$

If the spaaker will be unavailable at these numbers during the 45 days following the abstract dasdline, list phone numbers to be used instead.

Orivice Phone

Home Phone

(9) MAILING INSTRUCTIONS (Addreseses on roveree.) WVITED ABSTRACTS: Mail original + 5 copies DIRECTLY TO THE CONVENER. VOLUNTEERED ABSTRACTE: Mail Original +8 copies to the appropriate address to arrive on or before the deadline. Abatracts may NOT be eont by fax. 


\section{$\bullet$}

starting near the contact of the country rock and going into the metagabbro for a dstance of 65 feet. The country rock contains an assemblage of alkali feldspar. plagioclase, quartz, biotite, apatite and magnetite. The metagabbro contains an assemblage of plagioclase, hurnblende, clinopyroxene, biotite, quartz, sphene, apatite and opaques. Chemical data show a decrease of $\mathrm{SiO}_{2}$ and $\mathrm{K}_{2} \mathrm{O}$ from the edge of the metagabbro towards the center, and an increase in $\mathrm{CaO}_{2} \mathrm{Fe}_{2} \mathrm{O}_{3}, \mathrm{MgO}$, $\mathrm{TiO}_{2}, \mathrm{P}_{2} \mathrm{O}_{5}, \mathrm{~N}, \mathrm{~V}$, and $\mathrm{Cr}_{2} \mathrm{O}_{3}$. The $\mathrm{Al}_{2} \mathrm{O}_{3}$, and $\mathrm{Na}_{2} \mathrm{O}$ content rema in nearly constant. Hand samples stained with sodium cobalinitrite $17 s 0$ reflect decreasing $\mathrm{K}_{2} \mathrm{O}$ towards the core of the body. These chemical gradations may be due to metasomatism, assinilation of country rock or true compositional zoning during crystallization of an alkali-rich gabbro.

\section{№ $\quad 3795$}

THE SUMMIT, NEW YORK EARTHQUAKE OF JUNE 17, 199]

WALCOTT, Jessica and REVETTA, Frank, Department of Geology, Potsdam College of the State University of New York. Potsdam, N.Y. 13676.

On June 17. 1991 an earthquake of magnitude 4.0 shook southern New York. The epicenter was located at $42^{\circ} 35.49^{\prime} \mathrm{N}$ Latitude and $74038.22^{\circ} \mathrm{W}$. Longitude by Lamont-Doherty Geological Observatory. This location is 40 miles southwest of Albany near the town of Sumit, N.Y. The earthquake was felt strongly in the Albany-Syracuse area, southward in Rockland and Westchester counties, and westward in the Rochester area. The earthquake was unusual in sense since it occurred in the Catskili Mountains, an aseismic area where relatively few earthquakes occur. Also the epicenter was located just 18 miles northwest of the Gilboa Dam however no damage was reported at the dam.

The focal depth of the event was reported as $13 \mathrm{kms}$. This focal depth puts the hypocenter well within the Precambrian rocks since the elevation of the Precambrian basement is $-3 \mathrm{kms}$ in the epicentral region. The epicenter is located near a north-south trending horst structure in the Cambro-Ordovician and Precambrian rocks and along a series of northeast trending topographic linear features showr. on a brittie fracture map of the area. The location of the epicenter and focal depth of $13 \mathrm{kms}$ suggest the horst structure or northeast fractures may have been reactivated by stresses in the area to produce the earthquake and that the structure extends to a greater depth of possibly $10 \mathrm{kms}$. An historical earthquake search indicates that at least 9 other earthquakes occurred in the area since 1877 . Two of the epicenters of these earthquakes are aligned along the horst structure.

\section{9}

DIGITAL CONTINUOUS SEISMIC REFLECTION PROFILES OF NEW JERSEY INNER SHELF SAND RIDGES

WALDNER, Jotirey S. N.J. Geologkal SUney, CN427, Trenton, NW 08625 ; SHERIDAN,

Roban E., CAREY, John S., ASHLEY, Gail M., Dept of Geoboical Saences. Pulpers Universtly, Now Bnurswick, Now Jorsey, 08903, HENNE, Ruchard, G. Ji., N.J Goological Survey

Diptal continuous profiling seismic retlection data were collected along throe sand noges of the imer continental sholl of New Jersey in August 1992. The ecauistion system consisted of

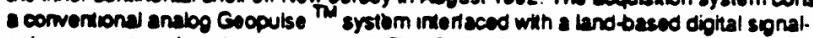
crnancement engineering seismograph. The Global Postioning System (GPS) was usod to ob. in a navigational ecourecy within 5 moters atter processing The rew data exhibit saismic milections trom layers less than 1 meter thick. The seismic trecklines were correlated to verecores tit and known geologic stratupraphy the dita show earty to late Hobcene deposilonal sequences overtying a mic-Wisconsinan barrier system bected at depths of 20 meters The eand ridoes oceur as constructive features sbove an uncontormity in an asymmetraal pro.

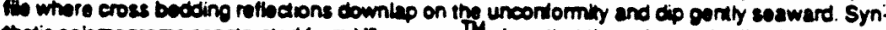
thetic selsmogrems consincted from Vbrecores th show that these internal reflections are eused by intertaces between shally gravel and medium sand. Dighal proties show processing creancemonts includino trace static comection, decomolution, whomatic gain scaling.

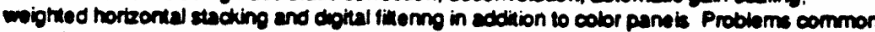

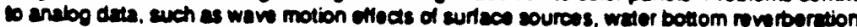

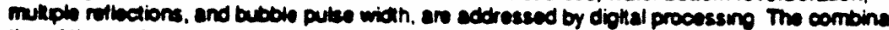

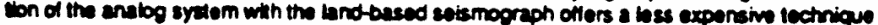
bor dipited equisition and processing, thus providing improved rosults over oldir anabo data.

\section{No 4413}

AN ACAOUN ALLOCHTHON IN THE HUMBER ZONE OF WESTERN NEWFOUNDLAND. MPLICATIONS OF INDUSTAY AND LITHOPROBE SEISMIC PROFILES

WNDRON. JWF. Geobogy Department, Sain Mary's Unverain, Halitex, Nove Sootia. B3H 3C3 Canada and STOCKMAL. G.S intervite of Sadimentary and Pelioloum Geology. 3033-33rd St N W. Caigary. Aborta. Canada. T2L 2A7?

in the Humber Zone of weatern Newioundland, Gremville age besement rocks ere exposed in the Long Range and indian Head Inters They are unconformably ovortain by a Cambnan

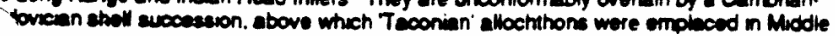

Ordovician time Ait the western edge of the Humber Zone post.Taconian pre-Acadian Wrata of the Long Point .. Clam Bank succession are deformed in a west-tacing monoclinal anceture. visible in indusiny seismic protiles and exposed at Pon au Port Peninsula This aructure is inierpreted as a inangle zone whin which the exposed sheff succession and overtying Taconian allochthon were transported westward in Acadian deformation

Canadian LITHOPROBE seismic proliles cross the Humber Zone near Stephenvilie (une 12) and east of the Bay of istands (lines 1-4) Line 12 shows subhorizontal reflectors beneath the indian Head masst and continuing eest between 3 and 45 s two-way travel time These are correlated with gently east-dpoing reflectors beneath the irangle zone oftshore and merpreled as the autochthonous shell succession The overlying assemblage of thrust thoets. mciuding the oulcropping basement and sheff succession is termed the Port au Pon Nilochithon

Lines 1 to 3 cross the sheff succession and Taconian allochthonous unis south of the Long Range Grenville massit Subhorzizontal reflectors. agair interpreted as aulochthonous platiorm andyor basement are well imaged west of Deer Lake between 2 and a ecconds nwo-way trevel time Discontinuous reflections can be traced farther west into the Bey of lelands ares

These observations suggest that the sourthern Long Range and ins cover are also abchthonous, transported at least $30.40 \mathrm{~km}$ westward in Acadian deformation Transverse anctures in the Humber Zone, notably at the southern margin of the Long Range and at Round Haad on the Port au Port Peninsula. are interpreted as hangingwall ramps formed by mectivation of obder normal tauts within the plaftorm succession

\section{NN 29428}

SOLUTION.-REDEPOSITION AND THE ORTHOCLASE-MICROCLINE TRANSFORMATION. EVIDENCE FROM ADIRONDACK GRANUITES WALDRON, Kum A. Dept. of Geology. Colgate Universitt, Hamilton. $N \gamma^{\prime}$ 13346; PARSONS, lan, Dept Geolog and Geophisics.

University of Edinburgh. West Mauns Rd. Edinburgh. EH9 3JW

Scolland. BROWN, William B.. CNRS.CRPG. F.54501.

Vandoeuvire-lè-Nancy cedel. France.

Feldspas microtextures in Adirondaci granulites suggest that the transformation of orthoclase to microcline has been accomplished by solution--redeposition

The orthoclase (OT)-nch par of an oplicall, mesoperthilic alkali feldspar was found to be cryptopenthiuc when examined bi transmission electron microscopi. A tw'o-stage thermal histon is proposed to explain the coarse and fine textures, w ith the cryptoperthite forming by: coherent exsolution belou $350-400^{\circ} \mathrm{C}$. Or parucular interest are areas $w_{1}$ thin the Or-nch cryploperthite $u$ here the predominant tu eed microlexture is cut by "seams" of microcline pasallel to $\mathrm{b}$ and the criploperthile lamellae The seams contan polyzonal microcline subgrains and micropores $(0.1$. $1.5 \mathrm{um}$ in diameter). Micropores have been linked $u_{i}$ th fuid-assisted subgrain formation and turbidits in feldspars. Subgrains. micropores and the tweed/microcline interfaces within the seams of ten have simple crystallographic indices charactensuc of the Adulana habit The Adulana habit is charactenslic of feldspar that has grown in low temperature veins or in sediments and appears to develop dunng in situ soluvon--redeposition of alkali feldspar. The cry stal habit of the microcline subgrains, the presence of micropores within the seams and the textural relationshup between the seams and criptoperthite lamellae suggest that lou temperature fluid infiltration resuliod in solution--redeposition of the alkali feldspai on a remarkably fine scale. Subsolidus recnistallization of feldspars in this fashion may have imporant geochemical implicauons, parucularly for 180 . 160 evchangc

\section{№ $\quad 2874$}

UTTHOSTRATIGRAPHY AND INTERNAL STRUCTURE OF THE OTTAUQUECHEE FORMATION, SOUTHERN VERMONT

WALSH. Grogory J. and RATCLIFFE, Nicholes M., U.S. Goological Sunvey, National Cemtor, MS 828, Reston, VA 22092

Mapping in south-central Vermom demonstrates that the Otruquechee Formation berminates as a mappeble unt in the vicinity of Andover, probably dus to fauth truncations. and is not continuous souttwerd to the Massachusetts border as shown on the Centennial Coologic Map of Vormont (Doll ot al., 1061).

At the typo locality in Briogewater (E.L. Perry, 1927, 15th Rapt. U. State Geol., p. 161) the Cambrian Othuquectioe Formation is $2.6 \mathrm{~km}$ thick and consists of black phyllite and dark-gray quatrite wth losece gray biotito-porphyroblastic phyllite, greenstone, and an quartoes ectiat. In Pyymouth the formation is $1.1 \mathrm{~km}$ thick and, in addition to the rock type of the type esction, the Otrauquechee contain gray biotite-porphyroblestic plagioclaso-quarte paragnsiss, green biotio-porphyroblastic chlorite-quartz schist, coppentinite, and thin ( $0.5 \mathrm{~m}$ ) discontinuous pods of gray calcareous quartzite, black dolomlic matble, and cray carbonato-chlorto-quare echist in a matrix of black phyllite and ellivery quetz-mice ectist. Noar Ludlow the formation is $0.4 \mathrm{~km}$ thick and contains black Dhyllite and dark-gray quartice, and in Andover it nartows to a single 3-m-thick dark-gray areterto.

Tho bet is chancterized by a north-striking cast-dipping ponotative sechistosity parallel to the contacts of the formation. Imernal inhostratigraphie units, however, traverse the formation from northeast to southwest suggesting that the internal lithoetratigraphy is colique to the structural trond. The imternal units are complexty isoclinally folded, and appoar to tinncale along intornal faults and along the western comtact with the Pinney Hollow Formation and the eastorn contact with the Stowe Formation. Lthoetratigraphic unts in the adjacom formations also truncate along the Ottauquechee contact. This evidence suggests that the Ortauquechee Formation torminates by truncation between turts as the bett is treced southward from the type locality. 
$\because$

\section{SAGEEP}

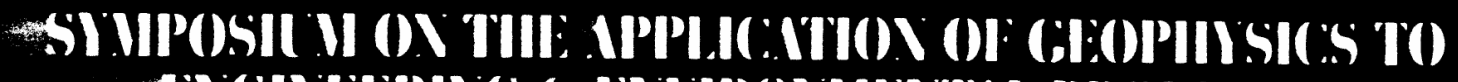

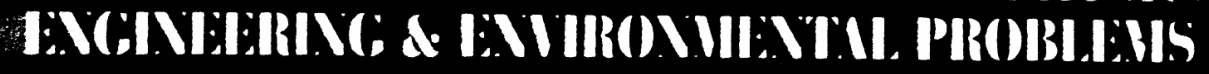

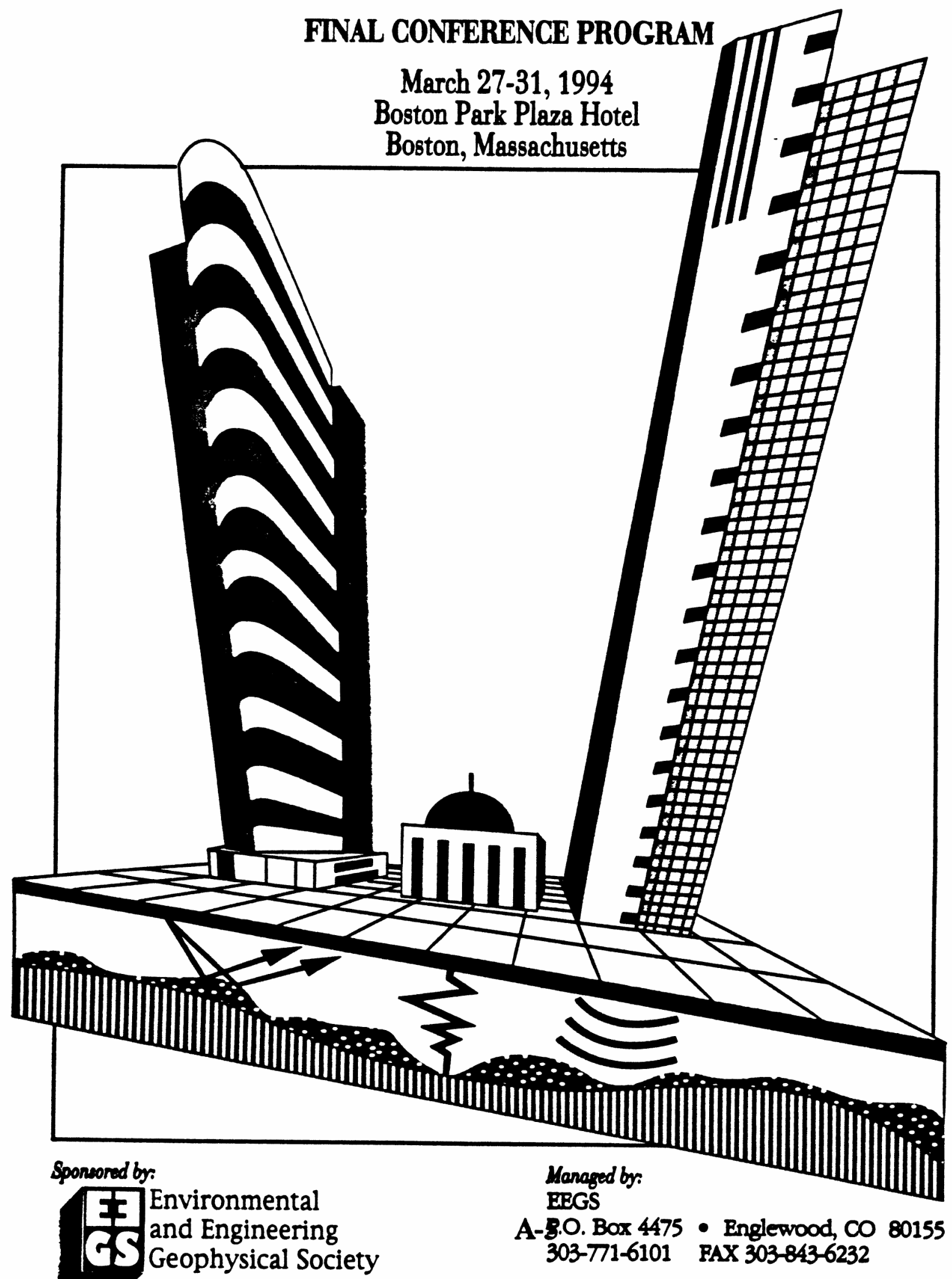




\section{T7pe Sympossium - comtinuced}

High-Resolution Flowmeter Logging - A Unique Combination of Borehole Geophysics and Hydraulics; Part II: Borehole Applications

Frederick L. Paillet; U.S. Geological Survey, Denver, CO; Crowder, Robert; COLOG Inc., Goldon, CO; Hess, Alfred E.; U.S. Geological Survey, Denver, CO

Monitoring Well Completion Evahuation with Borehole Geophysical Methods

Robert Crowder, COLOG Inc, Golden, CO

Fracture Identification Using Full Waveform Acoustic Logs

C.H. Cheng, Earth Resources Lab, Cambridge, MA

Use of Borehole Electromagnetic Induction and Natural Gamma Logs To Delineate a Contaminant Phume in Ground water

Thomas J. Mack, U.S. Geological Survey, Bow, NH

Analysis of Wellbore Image Data Applied to

Environmental and Geotechnical Case Studies

C.A. Barton, Stanford University, Stanford, CA; Wright, J.,

Geophysics Branch, U.S. Bureau of Reclamation, Denver, $\mathrm{CO}$

Assessment of Low-Level Radioactive Waste Using Borebole Spectra 1 Gamma-Ray Logging: A Case Study

from Port Hope, Ontario

Dirk Kassenaar; Leask, David; Garner Lee Inc, Niagara

Falls, NY; Zelmer, Bob, AECL Research, Ontario, Canada

Downhole Shearwave Studies Enhanced by Gamma Log

Uthologic Interpretations

D.L. Egger, Indiana Geologic Survey, Bloomington, IN;

Samuelson, A.C., Eckhoff W.R.; Ball State University,

Muncie, IN

Use of a Perforating Gun as a Downhole Seismic Source at the DOE Hanford Site

Susan Narbutovskih, Westinghouse Hanford Company,

Richland, WA; Michelsen, Finn, OYO Geospace,

Houston, TX

Tuesday, Marcb 29

800 am -1200 noon

\section{Poster Session III Site Characterization}

High-Resolution Geophysical Survey of a RCRA Site Gilein J. Steensma; Martin, Antony J.; Pendergraft; Darin M.; Johnson; Susan K.; Costa; Patti Kaye; IT Corporation, Irvine, $\mathrm{CA}$

STOLSTM Magnetic Surveys at the Sandia National

Laboratory and Offutt AFB

Jack Foley; Siegel, Robert; Geo-Centers, Inc., Newton

Centre, MA

Seismic Measurements of Ground Displacements at the Superconducting-Supercollider Site

Dale Morgan; Lesmes, David; Massachusetts Institute of

Technology, Cambridge, MA
Efilcient, Cost Efiective Waste Site Characterization Utllizing Complementary Non-Intrusive Geophysical Techniques: A Case Study of 2D and 3D GroundPenetrating Radar and Magnetometer Surveys W.R. Sims; Rucker, G.G.; Plunketh, R.A.; Westinghouse Savannah River Company, Aiken, SC

High-Resolution Marine Seismic Reflection Data Acquisition Using an Engineering Selsmograph Jeffrey S. Waldner, NJ Geological Survey, Trenton, NJ; Sheridan, Robert E., Rutgers University/Dept. of Geological Sciences, New Brunswick, NJ; Hall, David W., N] Geological Survey, Trenton, N]; Ashley, Gail M., Rutgers University/Dept. of Geological Sciences, New Brunswick, NJ;

Ground Penetrating Radar Survey of a Waste Disposal

Area at the Site of a Former Lumber Mill

J. R. Pelton, Boise State University, Boise, ID

A United Kingdom Environmental Geophysics Test and Training Stte

Ian Hill, Geology Department, Leicester University, U.K; Peter Fenning, Earth Science Systems Ltd., Harpenden, U.K.

The Integration of Imaging and Parameter Estimation in Shallow Geophysics

A.J. Witten; Norton, S.; Oak Ridge National Laboratory, Oak Ridge, TN; Devaney, A.J.; Schatzberg, Alon; Northeastem University, Boston, MA; Ursic, J., U.S. EPA Region 5, Chicago, Il; Dickson, W., Dynamic Graphics, Inc, Bethesda, MD

Tuesday, Marcb 29 1.00 p.m -5.30 p.m

\section{Poster Session IV Hydrogeophysics}

Finding Potential Brine Discharge Sites along the

Canadian River in Eastern New Mexdco Using

Electromagnetic Induction Methods

Jeffery G. Paine; Avakian, Arten J.; Gustavson, Thomas C.; University of Texas at Austin, Austin, TX

Utility of Ground Penetrating Radar in an Integrated Remote Sensing Program To Map Peat Depths in High Latitude Wetlands

Ramona E. Pelletier, NASA-John C. Stennis Space Center, Stennis Space Center, MS

Application of Through-Ice GPR in a Wetland

Investigation in Southwestern Michigan

William A. Sauck, Western Michigan University, Kalamazoo, MI

Identification of Hydraulically Conductive Fractures from the Analysis of Localized Stress Perturbations and Thermal Anomalies

C.A. Barton; Zoback, M .D.; Moos, D.; Stanford University, Stanford, CA 


\section{HIGH-RESOLUTION MARINE SEISMIC REFLECTION DATA ACQUISITION USING AN ENGINEERING SEISMOGRAPH}

WALDNER, Jeffrey S., Drexel University, Dept Civil and Architectural Engineering, Philadelphia PA - NJ Geological Survey, CN427, Trenton, NJ 08625 (609) 984-6587; SHERIDAN, Robert E., Rutgers University, Dept. of Geological Sciences, New Brunswick, New Jersey, 08903 (908) 932-2044; HALL, David W., NJ Geological Survey; ASHLEY, Gail M., Rutgers University.

A digital single-channel seismic reflection system was developed to acquire continuous profiling data by interfacing a conventional analog system with a land-based digital signal enhancement engineering seismograph. Digital profiles are enhanced by trace static correction, deconvolution, automatic gain scaling, weighted horizontal stacking and digital filtering. Problems common to analog data such as wave motion effects of surface sources, water bottom reverberation, multiple reflections, and bubble pulse width can be addressed by the processing. The fast firing-rate for analog records is maintained while a trigger-divider sends a slower trigger rate to the digital seismograph. An auto-save feature with an automatic roll-along switch groups adjacent traces to files, eliminating system limitations of the mass storage device.

The digital data were collected to map sand ridges of the inner continental shelf off New Jersey for beach sand replenishment surveys. The seismic tracklines are correlated to vibracores and known geologic stratigraphy. The digital data exhibit reflections from layers less than 1 meter thick. Synthetic seismograms constructed from the vibracore information show these internal reflectors are caused by shelly gravel/medium sand interfaces. Global positioning system (GPS) was used to plot real-time position as well as obtain a navigational accuracy within 10 meters.

The combination of the analog system with the land-based seismograph offers a less expensive technique for digital acquisition and processing. This provides improved results over older analog data. 


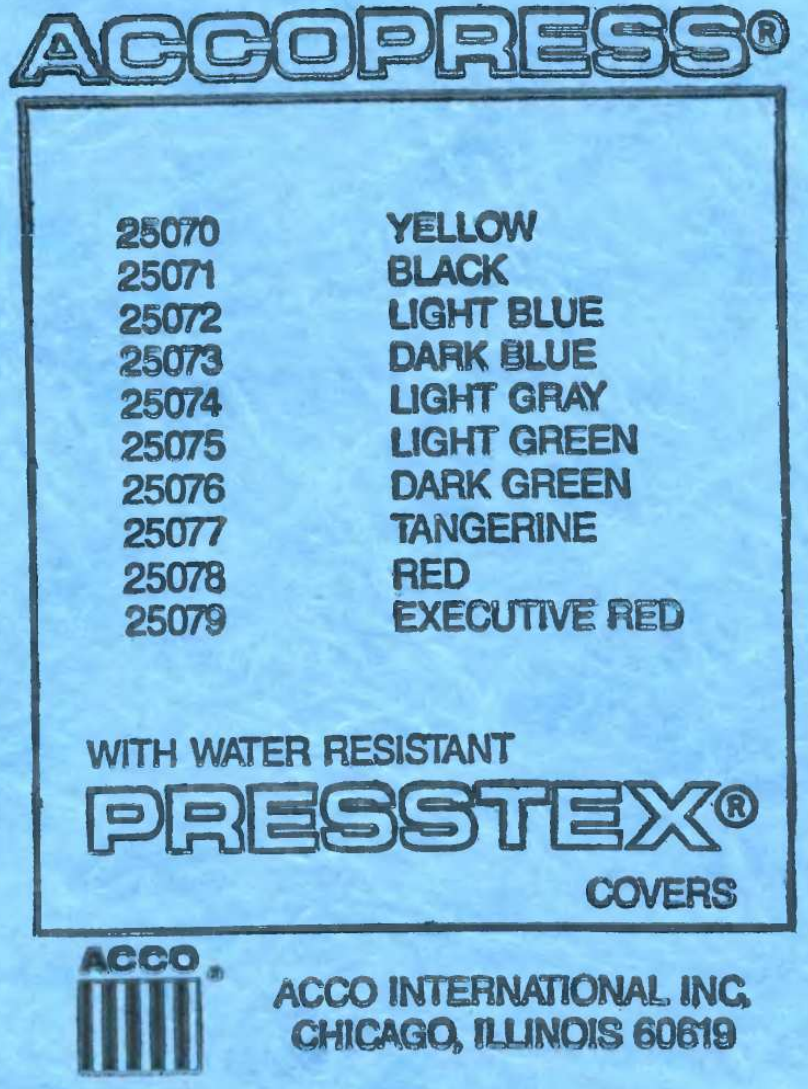

